\title{
Europe will fly animals on space station
}

[WASHINGTON] European researchers will be allowed to propose experiments using laboratory animals for the International Space Station, following an 11 to 1 vote last month by European Space Agency (ESA) partners in the project.

The move follows acceptance by Germany, the largest European contributor to the space station, that animals are essential for certain experiments in space. Work with higher mammals such as dogs and primates will still be forbidden. But researchers will be able to experiment with rodents, which ESA had prohibited in the past.

Many European scientists had seen the space agency's unwritten rule against rat and mice studies as a competitive disadvantage when proposing experiments in developmental biology, muscle deterioration and other areas of space research (see Nature 391, $733 ; 1998)$. The other major station partners — the United States, Japan, Canada and Russia-have no such prohibition.

Germany's long opposition to animal studies has been the main factor behind ESA policy. But the agency's life science working group, which gives advice on space biology research, lobbied over the past two years to have the ban removed.

"The real work was done country by country," says Didier Schmitt, head of life science research at ESA's ESTEC research centre in the Netherlands.

The German space agency DLR concluded in February that "animal experiments are unavoidable" for certain kinds of space research, says Günter Ruyters, head of the agency's life and microgravity sciences programme.

The German science ministry agreed, but

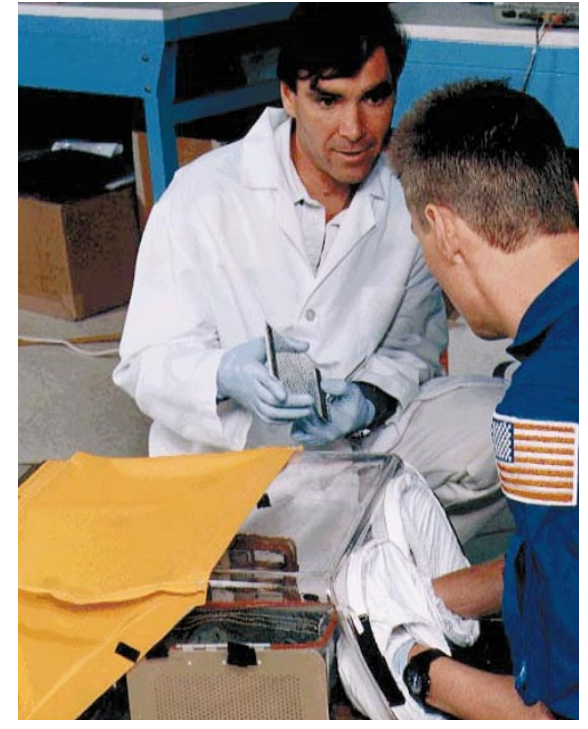

Learning experience: a Neurolab crew member is shown how to operate one of its rodent habitats.

stipulated that such experiments should be conducted only when there is no alternative, and when the scientific return is high. That cleared the way for Germany to vote 'yes' at a meeting last month of ESA space station partners to consider allowing animal studies.

Sweden cast the only 'no' vote, out of concern over possible political damage to the space station project. Per Magnusson of the Swedish National Space Board says European partners are taking a risk by approving experiments that a large fraction of the population opposes. Ruyters acknowledges that animal experiments are still "a very touchy issue" in Germany, where an already strong animal rights movement is gaining ground (see Nature 397, 461; 1999).
ESA's Schmitt says there is now an "urgent need" for an international committee to set ethical guidelines for animal experiments in space. That topic will be on the agenda at an international space life science working group meeting in Italy next week, which will also include a workshop on habitat design for rodents in microgravity.

Biologists learned hard lessons about how not to design such a habitat after dozens of newborn rats - more than half of those on board - died on last year's Neurolab Space Shuttle mission (see Nature 393, 4; 1998).

Before the flight, a plan to build a special cage for Neurolab was scrapped, and engineers modified an earlier design that had successfully housed adult rats, but not newborns. Problems with the young rats moving around on smooth (as opposed to mesh) surfaces in the cage in weightlessness may have contributed to the high death rate.

Visibility into the cage was also limited, which made it difficult to monitor the animals. A panel set up by the US space agency NASA and the National Institutes of Health to consider developmental biology research in space recommends that communications be improved among cage designers, scientists, astronauts and NASA managers to avoid such mishaps. And animals may need to be monitored more closely in orbit either by astronauts or by ground investigators through a video system — to ensure their health.

But such problems should be surmountable, according to the panel. Despite the loss of the Neurolab rats, the panel concludes that scientific results from the flight clearly demonstrate that complex animal studies are possible in space.

Tony Reichhardt

\section{UK's royal societies oppose new research council for Scotland}

[LONDON] Research in Scottish institutions should continue to be funded through the UK research councils once Scotland gets its own parliament and executive after elections next month, recommends a report by the Royal Societies of London and Edinburgh.

The report, published today (22 April), argues that any fragmentation of funding would harm Scottish science, for example if Scottish researchers were prevented from competing for UK-wide funds.

It adds that a larger overall science base is better equipped than a smaller one to weather changes to national research priorities. And it argues that a separate Scottish science base could harm the government's plans to develop Britain's knowledge industries, potentially impeding the flow of economic benefits from basic research to Scotland.
"A large-scale research system has a greater capacity to maintain research diversity, and thereby the flexibility to pursue new directions," say the two societies. "It is therefore important that devolution does not lead to fragmentation of basic science, engineering and technology (SET) in the United Kingdom, and that Scotland remains integrated within the UK system as part of the European SET base."

These conclusions are unlikely to be welcomed by the pro-independence Scottish National Party (SNP), which is running a close second to the Labour Party in opinion polls for the 6 May elections. The SNP would like the new parliament to be as powerful as possible.

The Labour government, on the other hand, may be more supportive. Labour has placed education and the knowledge economy at the heart of its Scottish election manifesto, promising to invest $\mathfrak{E} 100$ million (US\$161 million) in research infrastructure over the next three years.

The report's other recommendations include the appointment of a "senior minister" for science, and the creation of a science policy advisory board for the Scottish executive. Chaired by a senior scientist, this board would comprise representatives from research and industry.

Another senior scientist should be given responsibility for science advice to ministers, for the implementation of science policy, and for liaison with British science bodies, says the report.

The report adds that members of the Scottish parliament in Edinburgh will need their own source of independent scientific advice.

Ehsan Masood 